\title{
The Development of Work -Integrated Learning Model in Business Service Field for Rajabhat University, Thailand
}

\author{
Asst Prof Dr. Teeradet Chuenpraphanusorn \\ Dr. Ongorn Snguanyat \\ Jongkol Boonchart \\ Sarawut Chombuathong \\ Kanchulee Moonlapat
}

Graduate School Suan Dusit University, Thailand

Doi:10.5901/mjss.2017.v8n1p216

\section{Abstract}

\begin{abstract}
The Purpose of this research was four-folds; 1) to study and survey the needs for developing the Work -Integrated Learning Model in Business Service Field, 2) to develop and evaluate the model, 3) try-out the model and 4) to develop the hand books. This research was a mixed research between the Qualitative Research Methods by the documentary analysis and Quantitative Research Methods by the questionnaires with the 400 sampling group such; students, teachers, the business section, family by the Simple Sampling Random Methods and then by the Stratified Sampling Methods in 0.97 of Reliability, and the data was analysis by the statistic in term of percentage and mean. The results reveal by the following: 1) The trend and direction of the needs in Integration the Learning Management Model between the Institute and the Business Section was found that; the teacher, the business section or enterprise, curriculum, budget, teaching management and student were the main factors for developing the model.2) The result of the analytical of the Work-Integrated Learning in Thailand was found that; it was also emerged in the vocational field, especially in Service and Hospitality in the Vocational School, but in this research was concentrated in the Rajabhat University only, so the result pointed out directly through the Work-Integrated Learning of Rajabhat University in Thailand. The Model should be a) has a Pre-course Experience for training the student beforehand, b) has a Sandwich -course between the enterprise and University, c) Job Shadowing in the real situations and places d) Cooperative Education between the enterprise, university and another related business section e) Joint Industry University Course, f) Fields Work, g) New Traineeship of apprenticeship,h) Pro-Course Internship and, i) Placement to Practicum. 3) The result of try-out of the Model; it was found that the students were also Satisfied the model, especially the practicum in business section can help them to improve themselves in knowledge and practice their experiences a lot in highest ranking in 4.87, the secondly can help them to improve their confidence to select the job after finished from University in highest ranking in 4.81, the third can help them to improve their confidence in working both in Thailand and abroad in highest ranking in 4.80, and the latest result; was learning with the Work-integrated model can help them to improve their knowledge, skills and also making the good attitude toward this Model in high ranking 4.28. 4) The hand book was also included; 1) the concept or the principle of the Work-Integrated Model of Rajabhat University in Thailand, 2) the philosophy of the Model, 3) the purposes or the goals of the Model, 4) the competency of the students or the student out-put after used this Model, 5) the student learning's duty, 6) the scope of learning, 7) the learning process that it was integrated with language and technology (Work-Based Learning Integration with Language and Technology) including with the In-put, Process and Out-put.
\end{abstract}

\section{Background and significance}

It is fact that without a well-educated population, a sustainable national development cannot be continually carried out. Therefore, educational institutions serve as the second most important institution of the country after the family institution. They promote development of the national population according to the philosophy of sufficiency economy, starting from early childhood education, elementary education and secondary education to higher education, which is the most important as it is the last educational level before students graduate from universities and serve society.

The Higher Education Commission prepared the $11^{\text {th }}$ Higher Education Development Plan (2012-2016), in line with the $2^{\text {nd }}$ Fifteen Year Higher Education Framework Plan (2008-2022) which is a proactive plan indicating the direction and goals of Thai higher education development in the long term. It is also a master plan for the three Five Year Higher Education Development Plans, comprising the $10^{\text {th }}$ Higher Education Development Plan (2008-2011), the $11^{\text {th }}$ Higher 
Education Development Plan (2012-2016), and the 12th Higher Education Development Plan (2017-2021), which were approved by the Cabinet on 15 January 2008 (Office of the Higher Education Commission).

However, the implementation of the Higher Education Framework Plan prepared by the Higher Education Commission cannot continuously and concretely achieve the determined objectives and goals, either in the short or long term. Current higher education in Thailand still faces quality issues in many aspects, i.e. 1) Quality of graduates: Graduates cannot analytically think, scrutinize, or solve problems. They do not possess the basic knowledge necessary for their work in the future. They lack motivation for learning and fostering social conscience. Today, graduates value the degree over the skills and knowledge necessary for their occupation 2) Quality of instructors: Instructors lack deep knowledge and skills of their courses. They do not have responsibility, nor discipline. The teaching revolves around course content without adding discipline, morality or ethics in the learning process. 3) Graduate production and education management: The teaching covers only in-class learning without coordinating with external agencies. The quality of graduates does not fulfill the labor market's demands at the current time or for future eras. The curriculum does not include skill development or practices of different professionals. (Wichit Srisa-arn, B.E. 2552)

The main mission of higher education institutions is to produce quality graduates reflecting the demands of society and the labor market, in line with academic and occupational standards prescribed by the relevant agencies. However, the quality of Thai higher education does not meet the determined goals as evident in the world's university rankings (World University), published in the magazine Time Higher Education World University (THES) for the period 2013 2014. There were no Thai higher education institutions ranked among the first 200 universities. In comparison with other Asian countries, higher education institutions of China, Japan, Hong Kong, Taiwan, South Korea and Australia were among the top 200 ranks.

Hence, the ranking should be taken into consideration to find reasons why educational institutions in Thailand cannot compare with institutions of other countries. The future is expected to be even fiercer with competition, especially with the emergence of AEC. Thai educational institutions need to examine themselves and find solutions for continual development, and support and bring about advantages for future graduating students.

The process to bridge the educational gap and develop the quality of graduates relies on various factors, ranging from cooperation with enterprises and occupational associations, domestic and foreign cooperation of the same level (i.e. cooperation with domestic and foreign universities which offer courses of the same or similar field) and cooperation of the different levels (i.e. cooperation with interested external agencies, graduate employers, parents and students).

Thai Rajabhat universities cover 40 governmental universities around the country which offer Bachelor Degree courses, Master Degree courses, and Doctoral Degree courses. They adhere to the common philosophy which is "Become a local university for the sustainable development of local regions according to the philosophy of sufficiency economy". More than 30 years ago, Rajabhat universities offered higher education programs in the fields of the service and tourism industry before any other university in Thailand. Rajabhat universities began offering courses for service businesses since they were teacher colleges under the supervision of the Teacher Training Department until now as a vocational education provider.

However, the graduate production process of most Rajabhat universities have remained the same and lacks serious skill training and cooperation with external agencies. As a result, graduating students cannot apply the knowledge they learn to their work. Despite some Rajabhat universities that did adopt different models and methods of education management administration and do provide a good education and course curriculum, these universities are still unable to serve as models for other Rajabhat universities as their principles, methods and models are not fully developed to fit with the overall context for Rajabhat universities to be considered as 'local universities' that produce more than just graduates to serve society year after year.

The teaching method of Work Integrated Learning (WIL) has outstanding features in connection with involved sectors both isolated and far-reaching. They are 1) Benefits to students which are a) WIL can be a tool for problem solving, as it is an experience learning method, with which students have opportunities to adopt knowledge, working skills, and other specific skills in relation to their occupation. b) WIL provides opportunities for students to learn real-life work experience even before graduation. c) WIL opens opportunities for students to develop their social skills, such as cooperative learning skill and cultural and language exchange; and d) Graduates are equipped with specific knowledge and ability and can earn higher than unskilled students. 2) Benefits to instructors which are a) Instructors gain new experiences and knowledge from observing trainee students. b) Knowledge that instructors obtain from observing trainee students can be a base for providing instruction in other forms. c) Instructors will not make mistakes when they educate students with practical knowledge, as they have the real experiences themselves. 3) Benefits to educational institutions which are a) Universities bridge the educational world with the business world. b) WIL brings about learning exchange, acceptance, and trust in quality of graduates with entrepreneurs. c) With wide acceptance of the educational institution, 
their students are able to find jobs easier after graduation; and 4) Benefits to entrepreneurs which are a) Entrepreneurs acquire competent employees according to their demands, and do not waste time with new employee training b) Entrepreneurs participate in guiding students and setting curriculum which fortifies trust with occupational associations and boosts the entrepreneurs' image. It is undeniable that for Rajabhat universities, the development of Work Integrated Learning (WIL) can be a development process that creates new tools, models, and methods for education administration in the service industry field to efficiently respond to society's demands.

\section{Objectives}

1. To study and survey basic information in order to develop Work Integrated Learning (WIL) in the field of service businesses.

2. To develop and assess Work Integrated Learning (WIL) in the field of service businesses.

3. To try out Work Integrated Learning (WIL) in pilot universities and assess the experiment of WIL implementation

4. To improve models and create a manual of Work Integrated Learning (WIL) in the field of service businesses for the Rajabhat universities in Thailand for further publication.

\section{Hypothesis}

1. The developed learning model is effective and can be used as an integrated teaching method in the field of service businesses in Rajabhat universities

2. The results of implementing Work Integrated Learning (WIL) in the field of service businesses in Rajabhat universities achieves satisfactory levels.

\section{Methodology}

\subsection{Model development}

The population for collecting information in this research comprises 8,750 samples, divided into; 1 . Eight thousand students in the service business field in Rajabhat universities around the country 2. Two hundred instructors in Rajabhat universities around the country who teach service business courses (40 universities, 5 instructors per university) (Curriculum administrators and supervisors). 3. Three hundred and fifty personnel working in service business enterprises (100 persons from the tourism sector, 100 persons from the hotel sector, 100 persons from the restaurant sector, and 50 persons from the aviation sector). 4. Two hundred parents (50 persons from the northern region, 50 persons from the central region, 50 persons from the northeastern region, and 50 persons from the southern region)

\subsubsection{Samples}

Sample size of this research is determined by Taro Yamane's formula with a 95\% confidence level and a 5\% of maximum margin of error. Using the Simple Sampling Random method, the sample size covers 383 persons (the researcher selects 400 persons).

\subsubsection{Research tools and tool quality check}

The research tool for collecting information is a questionnaire designed according to the research objectives. It is based on studying theories, documents, textbooks and research related to the development of Work Integrated Learning (WIL). The questionnaire is divided into 6 parts as follows: 1) General information about the respondent checklist 2) Questions regarding the direction and conditions of the teaching method in the service business field in educational institutions using a 5 point rating scale 3) Trends, direction and demand of Work Integrated Learning (WIL) in educational institutions and enterprises. The questions in this section use a 5 point rating scale 4) Direction and methods of cooperation between educational institutions and entities involved with graduate production such as enterprises and occupational associations. The questions in this section use a 5 point rating scale 5) Main competencies of graduates in the service business field according to demands in the labor market. The questions in this section use a 5 point rating scale. 6) Open-ended questions. The respondent can express their opinions about the development of Work Integrated Learning (WIL). 


\subsubsection{Research tool design: Step 1}

The researcher studies documents and research related to competent performance in the field of service businesses, Work Integrated Learning (WIL), Thailand qualification framework and research tool design.

The researcher designs the questionnaire according to the determined scope and content under the conceptual framework and research scope.

Questionnaire validity and reliability test comprises the following steps:

Validity: The researcher presents the questionnaire to 3 experts (as indicated in the appendix) to check its accuracy and content validity and whether the tool is relevant to the measured content. The experts also check the language used, format and statements. Then, the researcher revises the questionnaire according to their recommendations.

Reliability: The researcher conducts a try-out of 30 sets of the revised questionnaire with a sample group similar to the actual sample group. The alpha coefficient of reliability for the questionnaire is 0.97 .

\subsubsection{Data analysis}

1. The analysis of general information of respondents is conducted by finding frequency and percentage. The analysis is presented with tables and narrative descriptions.

2. The analysis of information in section $2-5$ is conducted by finding frequency, percentage, mean and standard deviation. In the $2^{\text {nd }}$ step, the analysis is presented with tables and narrative descriptions to develop and assess Work Integrated Learning (WIL) in the field of service businesses. This step consists of 2 minor steps which are:

1) Model development of Work Integrated Learning (WIL) by workshop which includes 1) Seven researchers 2) Four instructors teaching the service business (one instructor from each region) and 3) Four students studying in the field of service businesses in Rajabhat universities (one student from each region) selected by purposive sampling. In total the workshop is attended by 15 persons. 2) Model assessment by model critics technique conducted by experts comprising 1) Seven researchers 2) Four persons of curriculum administrators I heads of department / service business curriculum presidents 3) Four senior students who have passed learning development of other methods 4) Four persons of entrepreneurs / graduate employers / occupational association members in the service business field 5) Four parents of students selected by purposive sampling. In total the assessment is conducted by 23 persons.

\subsubsection{Research tool}

Tools for model critics technique consist of a) The developed manual with all details according to performance indicators and step/process of instructions b) Evaluation form according to performance indicators and step/process of instructions c) Tape recorder to record model critics.

\subsection{Model implementation: To try-out the Work Integrated Learning (WIL) in pilot universities and assess the experimented model}

\subsubsection{Population}

The population in the research is divided into 2 groups: One hundred and sixty students in the service business field in the three pilot universities which are Chiang Mai Rajabhat University, UdonThani Rajabhat University, Suan Dusit Rajabhat University. Twenty nine instructors who observe trainee students of pilot universities in enterprises. Eighteen mentors whose enterprises appoint the guides and supervisors of the trainee students.

\subsubsection{Samples}

Ninety students in the service business field in the pilot universities (30 students are selected by purposive sampling from each university).Three instructors who observe trainee students of the pilot universities in enterprises (1 instructor is selected by purposive sampling from each university).

Three mentors whose enterprises appoint the guides and supervisors of the students under training (1 student 
mentor is selected by purposive sampling from each university).

\subsubsection{Tools and tool design}

\subsubsection{Tool}

This step contains 3 types of tools: 1) Student performance evaluation form for entrepreneur evaluation of student performance in enterprises. 2) Student satisfaction/attitude evaluation form toward Work Integrated Learning (WIL) for student self-evaluation. 3) Interview form concerning the Work Integrated Learning (WIL) pilot program for mentors in the enterprises, students and observing instructors.

\subsubsection{Tool design}

1. Student performance evaluation form is developed as follows: 1.1)The researcher studies documents, models, directions, performance evaluation methods, by reading documents and inquiring about the enterprises. 1.2)The researcher determines performance evaluation points according to determined indicators.1.3)The researcher edits research information and creates the tool structure with recommendations from the experts. 1.4) The researcher creates the evaluation form according to determined scope and content under the conceptual framework and research scope. and 1.5)The researcher tests the validity of the evaluation form by presenting the form to the three experts for their consideration (as indicated in the appendix) to ensure validity and content validity. The experts check whether the designed tool is relevant to the evaluated content, examine the language, format and statements. Then, the researcher revises the form according to the experts' guidance.

2. Student satisfaction/attitude evaluation form toward Work Integrated Learning (WIL) for student self-evaluation is developed as follows: 2.1) The researcher studies documents and research related to evaluation, evaluation models, evaluation methods, evaluation lists of attitude and performance, indicators and tool design. 2.2).The researcher edits information and creates the tool framework with recommendation from the experts. 2.3) The researcher creates the attitude evaluation form with questions according to determined scope and content under the research conceptual framework and scope. 2.4) Validity and reliability test is conducted as follows: 2.4.1 The researcher tests the tool's validity by presenting the satisfaction/attitude evaluation form to the three experts for their consideration (as indicated in the appendix) to ensure validity and content validity. The experts check whether the designed tool is relevant to the evaluated content, examines the language, format and statements. Then, the researcher revises the form according to the experts' guidance. 2.4.2 The researcher conducts a try-out of 30 sets of the revised questionnaire with a sample group similar to the actual sample group. The alpha coefficient of reliability of the questionnaire is 0.97 .

\subsubsection{Data analysis}

The researcher checks the completeness of all questionnaires collected from the sample group and encodes the data to determine frequencies and analyze the statistics as follows: 1) The general information of respondents is analyzed with frequency and percentage. The analysis is presented with tables and narrative descriptions. 2) Student satisfaction/attitude toward Work Integrated Learning (WIL) is analyzed with frequency, percentage, mean and standard deviation. The analysis is presented with tables and narrative descriptions.

\section{The Research Result}

\subsection{Data conclusion}

1. The instructor factor is the most important factor to the development of a students' body of knowledge. It is found that enterprises can greatly contribute to teaching method, especially in the practical and training levels where students learn from real-life experiences in the enterprises.

2. The curriculum factor is an important part for the integrated learning. To enhance student competency, the curriculum must be based on learning with morality, ethics, service-mind and responsibility, together with real practices, under standards of service businesses such as hotel, tourism, etc. 
3. The fund and facilities factor. The educational institutions should provide modern learning media suitable to the vocational context of students. They should increase the budget for many expenses, for example tool and equipment expenses for student occupational practices. Most importantly, in the educational institutions, there should be enough modern practice rooms for students, so that all students can practice what they learn.

4. The instruction factor. The instruction in classes, practice rooms and work places should be various in both models and methods. The instruction should emphasize integration between theories and occupation, study trip and occupational performance of students.

\subsection{Hypothesis test}

1. The first hypothesis: Different groups of respondents have different opinions toward direction and demand of WIL in educational institutions and enterprises. The result of the t-test indicates that different groups of respondents have different opinions toward direction and demand of WIL in educational institutions and enterprises with a statistical significance of $.001(t=5.388, p=.000)$. When considering each aspect, it is found that the $2^{\text {nd }}-6^{\text {th }}$ factors are different with a statistical significance of .001 . The $1^{\text {st }}$ factor is different with a statistical significance of .01 .

2. The $2^{\text {nd }}$ hypothesis: Different respondents of different genders have different opinions toward direction and demand of WIL in educational institutions and enterprises. The result of the t-test indicates that the different respondents of different genders do not have different opinions toward direction and demand of WIL in educational institutions and enterprises $(t=0.177, p=.860)$. When considering each aspect, it is found that the $2^{\text {nd }}$ factor regarding instruction is different with a statistical significance of .05 . The other factors are not different.

3. The $3^{\text {rd }}$ hypothesis: Different respondents from different regions have different opinions toward direction and demand of WIL in educational institutions and enterprises. Based on mean and standard deviation, direction and demand of WIL in educational institutions and enterprises are divided according to the respondent's region. The researcher tests the hypothesis with one-way ANOVA analysis. It is found that respondents from different regions have different opinions toward direction and demand of WIL in educational institutions and enterprises with a statistical significance of $.001(F=5.463, p=.001)$. When considering each aspect, it is found that the $3^{\text {rd }}$ factor regarding students/performance and the $4^{\text {th }}$ factor regarding enterprises are different with a statistical significance of .001 . The $1^{\text {st }}$ factor regarding curriculum is different with a statistical significance of .01 . The $5^{\text {th }}$ factor regarding instructors is different with a statistical significance of .05 . The $2^{\text {nd }}$ factor regarding instruction and the $6^{\text {th }}$ factor regarding funds and facilities are not different.

\subsection{Results of WIL in the field of service businesses}

\subsubsection{Curriculum features and models}

It is found that the curriculum is developed under a clear direction, as indicated in the interview that "The curriculum development is done according to the developmental process. The curriculum is designed by the experts in the field and in line with opinions of entrepreneurs and critics of academics." (Interview, 8 January 2016). It is an important feature of curriculum development to meet the standards and demands of the labor market. Another interviewee asserts that "The curriculum currently used is an integrated curriculum, as the business sector wants multi-functional personnel rather than pure science personnel. The development process is as follows: Firstly, the demands of graduates in the business sector is surveyed under the cooperation project and the original curriculum is improved accordingly through integration between IT courses and marketing courses, etc. As a result, the number of courses decreases but the students can study more various course content and completely according to the prescribed curriculum." (Interview, 2 December 2015)

Based on the in-depth interview, it is found that curriculum development in the field of service businesses relies on key environments such as the enterprises and graduate employers. One respondent asserts that "In the recent curriculum development, the universities allow the enterprises to participate in the curriculum development, by mutually thinking, developing, administrating and educating, which is beneficial to the universities." (Interview, 11 November 2015)

In addition, another benefit of enterprise participation in the curriculum development is that "The entrepreneurs allow students to be trained for work in their enterprises. Therefore, roles and duties of the enterprises are not limited to employment. Now they participate in the development of the graduates." (Interview, 8 January 2016)

The changing role of enterprises reflects the changing cooperation between the educational institutions and the 
enterprises under the mutual agreement. Most courses emphasize integration of different sciences, as stated "Courses in the curriculum are more interdisciplinary. Instructors have qualifications and knowledge in the field of services, both tourism and hotels." (Interview, 2 December 2015)

Value-added of students is important for instruction in the service business field, for example "The department concludes that foreign language proficiency is essential for students. Hence, our curriculum contains more foreign language courses than other departments in the university. Aside from English, there are Chinese, Vietnamese and other courses offered as selective subjects which students can choose according to their interests." (Interview, 17 December 2015)

In conclusion, features and models of curriculum are interdisciplinary and integrate all sciences to support the academic strength and occupational competency of students.

\subsubsection{Directions of instruction}

Directions of instruction in educational institutions are different in both models and methods which can be divided as follows:

\subsubsection{In-class instruction}

It is found that instructors have various instruction directions, for example "Instruction of all courses covers both theories and practices, so that students can fully practice their practical skills. For example, students enrolling in the bartender course can seriously practice their skill in a practice room or simulation room designed according to hotel rooms." (Interview, 8 January 2016)

Almost all course instructions are done with simulation of real situations, especially tourism courses, because problems and obstacles can occur anytime in the real work life. This instruction model gives immunity to students when they face reinstruction model gives immunity to students when they face real problems. In general, students like and respond to this instruction method quite well. Particularly, students of Rajabhat university believe that they are not as good as students of other universities, however, practice give them self-confidence. It becomes an outstanding feature of our university. Entrepreneurs always praise students of Rajabhat universities for their hard working character. (Interview, 2 December 2015)

At the same time, the instruction based on different aspects such as problem based learning, community based learning, company based learning or company to works, encourages students to be more eager for learning. As for the inclass instruction of all courses, experts are invited to classes to exchange their knowledge and offer advices to the students. In addition, this instruction method encourages students to express their academic opinions which challenges their shy nature. Initially, our students are relatively shy. This could be because of the rural location of our universities and the students' simple life." (Interview, 11 November 2015)

The seminar courses are no less important than other courses as they summarize learning of all sciences. They serve like a comprehensive examination at the Master's Degree level. In the field of tourism, there are always new topics and issues, for example new diseases. In these courses, students learn and mutually find solutions. At the same time, the curriculum requires students to do their projects after attending the seminar classes, by which they practice work cooperation skills, thinking skills, and information searching and conclusion skills. (Interview, 17 December 2015)

\subsubsection{Outside-class instruction}

The universities promote outside-class instruction, as indicated in the interview. "Our instructions do not revolve around in-class instruction only. Beginning from the student's first year in the university, we start with developing their personalities." (Interview, 11 November 2015)

The study trip to the enterprises is important and necessary for studying businesses in the service industry. The universities arrange the study trips in and outside the province, based on reputation, quality and globalization of the business. With the study trips, students can observe real work in their field and jigsaw their ideas. (Interview, 17 December 2015)

In conclusion, the teaching method at Rajabhat university includes both in-class and outside-class instruction according to the occupational field that the students choose. 


\subsubsection{Training and following-up}

All three Rajabhat universities have similar education management administration which is centralized-decentralized administration. It is a flexible and cooperative administration where presidents of curriculum and heads of department are the main entities of each administration. Their main duties are as follows:

\subsubsection{Prior to training}

Administrators of department, presidents of curriculum and heads of department select the enterprises based on the following criteria: 1) The training in the previous year. They consider the administration system, safety, and attention of the enterprises according to information collected by trainee students from the previous year 2) Cooperation with the domestic and foreign enterprises and their training administration network 3) Offers from the enterprise requesting for trainees.

\subsubsection{During training}

During student training, the universities dispatch instructors to observe their training. The observation contains the following details: 1) Perspective from the observing instructors: The instructors accompany the students in their first training to advise and clarify training conditions to students, and acknowledge the training conditions prescribed by the enterprises (Interview, 8 January 2016). 2) Perspective from the enterprises includes a) Positive perspective (i) Students are hardworking and patient (ii). Students are polite and humble (iii) Students are disciplined (iv) Students dress politely (v) Students love to learn new things (vi) Students are obedient (vii) Students like to participate in activities (viii) Students are friendly and can get along with everyone (ix) Students can adjust themselves to different situations ( $\mathrm{x}$ ) Students are not arrogant b) Opinions on improvement and correction (i) Students are unable to communicate in foreign languages such as English, Chinese, and Japanese (ii) Students lack computer skill and communication technology skill (iii) Students lack thinking and decision making skills (iv) Students lack leadership skill.

\subsubsection{After training}

After training, the universities receive the assessment from the enterprises and observing instructors using evaluation forms prepared by the university to obtain assessment results of the students' performance. (Interview, 8 January 2016) In addition, the universities hold seminars where students can exchange and formulate bodies of knowledge obtained from the training. In the seminars, the students conclude the advantages and disadvantages of the curriculum which need further improvement in the future. (Interview, 17 December 2015)

At the same time, the universities receive feedback from the entrepreneurs with regard to the students' qualifications. It is found that the students of Rajabhat university are patient, determined, obedient and not fussy. However, they lack English language proficiency. Hence, the universities need to develop this skill of students the most. (Interview, 11 November 2015)

\subsection{Student satisfaction toward WIL}

Regarding student satisfaction toward WIL, it is found that with a mean score of 4.87, the students are satisfied with the training, since they gain real knowledge and occupational skills. In second place, with a mean score of 4.81 , students are satisfied with the training, since they are more confident of their future career. With a mean score of 4.80 , students are satisfied with the training, since they have more confidence applying for jobs in and outside the country. Lastly, with a mean score of 4.28 , students are satisfied with the training, since they have clear theoretical knowledge suitable with their occupation. 


\section{Research Result Discussion and Recommendations}

\subsection{Research result discussion}

\subsubsection{The instructor factor}

The instructor factor is the most important factor to the development of the students' body of knowledge. It is found that the enterprises can greatly contribute to the teaching method, especially in the practical, training and operational levels where students learn from real experiences in enterprises. In the instruction process, the instructor factor is important to the formulation of theoretical knowledge which is a core of integrated learning. Instructors can also mean knowledgeable and competent personnel in enterprises contributing to teaching method with the cooperation from many sectors. According to the research results, instructors are expected to have discipline, ethics and act as good role models for students. They should have insightful academic and occupational knowledge, and possess a good attitude toward students and their occupational field. Hence, it can be concluded that the instructors are important to this teaching model.

\subsubsection{The curriculum factor:}

The curriculum factor is another significant part of integrated learning. To enhance student competency, the curriculum must be based on learning with morality, ethics, service-mind and responsibility, together with real practices, under the standards of service businesses such as hotel, tourism, etc. The curriculum is important to learning the service business field, as it serves as a blueprint for building career knowledge. Therefore, the developed curriculum requires the study of demands of enterprises, students and involved sectors, as asserted by Seller and Alexander (1974) that the curriculum development should emphasize planning for the utmost achievement. The curriculum development should comprise the following steps: 1. Goal and objective determination 2. Curriculum design 3. Curriculum implementation 4. Assessment.

\subsubsection{The funds and facilities factor:}

The educational institutions should provide modern learning media suitable to the vocational context of students. They should increase budget for many expenses, for example tool and equipment expenses for student occupational practices. Most importantly, in educational institutions, there should be a sufficient amount of modern practice rooms for students so that all students can practice what they learn.

\subsubsection{The instruction factor:}

The instruction in classes, practice rooms and work places should be various in both models and methods. The instruction should emphasize integration between theories and occupation, study trip and occupational performance of students. The instruction in the field of service businesses should be learning through different forms. According to Michaelis (1972), instructions should have the following features: 1. Combining daily life experiences of students as a part of the instruction 2. Arranging study trips, so that students can learn from enterprises 3. Inviting experts or specialized speakers to give lectures, demonstrate, guide or educate students on a practical level 4. Allowing students to interview gurus or experts during study trips and work observations.

\subsection{Additional opinions}

Additional opinions obtained from collected information which should be discussed are as follows:

1. In integrated learning of the service business field, enterprises should participate in or become a part of the teaching method.

2. Instructions should emphasize primary occupational skills in service businesses such as foreign language skill, analytical thinking, problem solving skill, negotiation skill, etc.

3. The educational institution should make memorandums of understanding with institutions of the same or different levels and with enterprises in and outside the country.

4. In instruction, the students should have opportunities to practice occupational skills in the enterprises. The training can be conducted under some courses during school breaks or during semesters. There should be more than 2 training periods through the 4 year curriculum. 
It can be said that the information collected reflects the significance and real demands that enterprises have for graduates from Rajabhat universities. The above 4 items are factors which can enhance the capacity of students. For example, invitation of personnel from the enterprises or experts of different fields such as tourism, hotel and service to educate students in a practical level can be beneficial to the students. Students can receive clear knowledge consistent to their future career. The work and learning integration in different forms including MOU can be useful to students. The occupational skills in the field of the service industry is essential to the Thai economy, as more than $50 \%$ of the country's income is from tourism.

5. Synthesis result of WIL In most cases, WIL in the service business field in Thailand is found in vocational education, especially in the fields of services and industry. However, this research focuses on WIL in the service business field in Rajabhat Universities in Thailand. Vocational education in the service business field has been going on in teacher colleges for more than 30 years. The synthesis is based on the synthesis framework under the integration between WIL in Rajamangala University of Technology, Rajabhat Universities and globalized learning as follows:

a. Pre-course experience is a pre-requisite criteria used for the selection of students in consistency with their fields of study. The pre-requisites are as follows: 1) Students must have work experience in their fields of study, for example they have worked in tourism or hotel businesses for more than 1 year. 2) Students must meet specific qualifications such as determined weight and height.

b. Study and work course (sandwich course) took place for the first time in 1962 - 1963 in Australia. There are 2 types of sandwich courses which are 2.1 Thin Sandwiches 2.2 Thick Sandwiches. Students are required to practice their occupation in enterprises for $3-4$ months or half a semester under the enrolled course with different conditions. Many curriculums in higher education institutions require students to receive training in their last semester before graduation.

c. Job shadowing is a teaching method that requires students to learn real working behaviors in enterprises through socialization, observance, learning, and inquiry to absorb and formulate knowledge and skills in terms of both work and organizational cultures: for example, law experts, lawyers, tour guides, hotel staff, etc.

d. Cooperative education is the instruction which combines theories and practices to develop and increase the capacity of students in consistency with the demands of enterprises. It requires cooperation from the enterprises for developing instructions and student work practices. After graduation, students can continue working in the organization, as they have already passed the training as part of the curriculum in universities.

e. Joint industry university course is a curriculum developed under the cooperation of universities and enterprises. Enterprises may render some support for budgets and equipment for the development of students under the university curriculum.

f. Field work is a form of instruction under which students survey and observe enterprises for a short period and instructors and enterprise personnel provide primary knowledge in different fields such as science, business administration, management, geography, history, etc.

g. New traineeship or apprenticeship is the work practice with systematic process, method, preparation and clear structure in and outside enterprises, such as flight attendants, veterinary, etc.

h. Pre-course internship is learning and practice to enhance practical experience after graduation, for example physicians and lawyers.

i. Placement to practicum is the development of skills and experiences necessary for the future through additional training under real situations, for example physicians, nurses and teachers.

It can be said that the above instruction methods are occupationally goal-oriented instruction or career path-based instruction. They promote efficiency of work skills. These instructions methods strengthen the performance and potential of students, as students are equipped with knowledge and capacity and a widened occupational outlook. However, the said processes or instructions are quite rare in Thailand where most instruction is content-based rather than practicum based or career based.

\subsection{Recommendation}

\subsubsection{Practical recommendations}

1. Universities can adopt this research with their teaching method. At the same time, they should maintain the 
direction and form of the main framework that the universities have originally determined. The implementation of the results of this research should be adopted within the context of each university's teaching method.

2. The integrated learning which the researcher has developed can serve as an instruction model which universities can use to enhance student academic competency and practical skills, as the developed instruction method is flexible and can be adjusted according to student groups or the university's direction and policy.

3. There should be research regarding WIL in enterprises and educational institutions for a full-time curriculum which can bring about the utmost benefits for students. WIL should not be limited to just student training in enterprises.

\subsubsection{Policy recommendation}

1. All Rajabhat universities should set up policy and direction for development of students in the service business field so that they are knowledgeable in theories and real practices.

2. All Rajabhat universities should set up policy of formal cooperation between all sectors involved with the teaching method; cooperation of the same level, such as cooperation between departments in the same university and departments offering Bachelor's Degree courses in the same field; and cooperation of different levels, such as cooperation from enterprises and governmental and private organizations, to attain their participation in the teaching method.

3. Policy regarding student development in consistency with the demands of the labor market should not be just a policy. It can be a university's strategy, and developed as a base for other plans and activities for concrete practical development. This will further support and pave the way for the advancement and value-added of students in Rajabhat university.

\section{References}

Bandaranaike \&Willison. (2011). Engaging Students in Work Integrated Learning: Drives and Outcomes. [Online]. Available : http://www.waceinc.org/philly2011/conference roceedings/Refereed\%20Papers/Australia/ SUNITI 1.PDF.

Brown, W.B. \&Moberg, D. J. (1980). Organization Theory and Management : A Macro Approach.New York : John Wiley and Sons.

Canadian Association for Co-operative Education. Co-operative Education Manual. Available from : URL http://www.cafce.ca. Accessed FEB 102016.

Collins Cobuild, (1987). Dictionary Eng/sihLanguage.London : William Colins Sons And Col,Ltd.

Curtis, R. Finch \&Jhon, R. Crunkilton. (1979). Curriculum Development in Vocation and Technical Education. Boston, Massachusetts : Allyn and Bacon Inc.

Good, Carter V.(1973). Dictionary of Education. New York : McGraw-Hill.

Gutex Gerald L. (1988). Education and Schooling in America. New Jersey :Prentice.Hall.

Filiciano,Gloria.(1983). Training in the Development and Use of Folk Media and Mass Media in Field LevelCommunication Strategies.UNESCO Report Folk Media and mass media in Population Communication 8 (march) : 8.

Ivancevich,JM. And others.(1989). Management : Principles and Function. $4^{\text {th }}$ ed. Bostion : Richard D. Irwin,Inc.

Joyce,M. \& Well.(1986). Model of Teaching.Newyork :Prentic-Hall.

Keeves, Peter J. (1988). "Model and Model Building," Educational Research Methodology and Measurement : An International Handbook.Oxford :Pergamon Press.

Linn,P.L. Howard, A. \& Miller, E. (2003). Handbook for Research in Cooperative Education and Internships. New York : Lawrence Erlbaum Associates.

Luca, I. (2004). ESP Syllabus Design for Tourism Students. Latvia : School of Business Administration Turiba Latvia.

Michaelis, J.U. (1972). Social Studies for Children in a Democracy : Recent Trends and Development.Englewood. Cliffs, New Jersey : Prentice - Hall.

Oliva, Peter F. (1988). Developing the Curriculum. $2^{\text {nd }}$ ed. Illinois : Scott, Foresman and Company.

Saylor, J. G. \& W.M. Alexander. (1974). Planning Curriculum for school. New York: Holt Rinlhast and Winston.

Tan SooiBeng. (1992). Towards a Social Historical Ethnomusicology :Bangsawan as case study. Malaysia.

Taba, H. (1962). Curriculum Development: Theory and Practice. New York: Harcourt, Brace

Tyler, Raeph. W. (1949). Basic Principles of Curriculum and Instruction. Chicago : The University of Chicago Press

Tyler, R.W. (1949). Basic Principles of curriculum and Instruction.Chicago :University of Chicago Press.

Vance, C. M., Sibeck, G., McNulty, Y., and Hogenauer, A. (2011). Building global competencies through experiential coursework in international travel and tourism. Journal of International Education in Business, vol. 4, no.1, pp. 30 - 41.

Willer,D.(1967). Scientific Sociology Theory and Method. New Jersey : Prentice - Hall. http://www.northernstudy.org ISufficiency_Economy_htm 